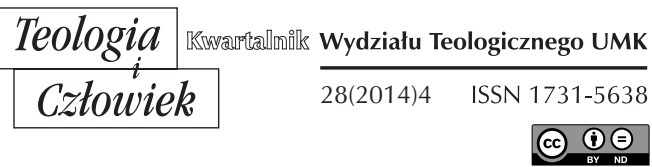

KS. WOJCIECH FRĄTCZAK*

TORUŃ-WŁOCŁAWEK

\title{
ŻYCIE KOBIET MAGNATERII POLSKIEJ W XVII WIEKU
}

DOI: http://dx.doi.org/10.12775/TiCz.2014.066

Dlaczego życie kobiet polskiej magnaterii jest na tyle ważne, żeby zajmowali się nim historycy? Ponieważ to one stanowiły elitę kobiet w Polsce. Ich zachowanie wpływało na modę i życie najpierw szlachcianek, a przez nie moda przechodziła na kobiety w miastach, głównie pochodzące $\mathrm{z}$ bogatego patrycjatu oraz z rodzin bogatszych rzemieślników. Ponadto o ich życiu wiemy najwięcej, bo zachowały się świadczące o nim relacje, pamiętniki, listy itp. O kobietach wiejskich trudno coś powiedzieć, ponieważ nie zajmowano się nimi, nie mamy zasadniczo przekazów mówiących o ich trudnym losie, wszak włościanie wówczas nie byli nawet uznawanym $w$ Polsce stanem.

Żyjemy w dobie powszechnej emancypacji kobiet, które pragną dorównać mężczyznom we wszystkim i przejąć nawet te najbardziej trudne zawody. Mamy więc kobiety w wojsku zarówno w broni pancernej, komandosach, jak i w marynarce, mamy policjantki, uprawiające boks, podnoszące ciężary, a nawet zawodowe killerki, czyli zabójczynie. Może tylko nie znam kobiet kopiących w kopalniach jako górnicy, ale to zapewne sprawa najbliższej przyszłości. Szkoda, że coraz mniej z nich

* Ks. dr hab. Wojciech Frątczak, kapłan diecezji włocławskiej, jest adiunktem w Katedrze Historii Kościoła i Patrologii na Wydziale Teologicznym UMK w Toruniu. 
chce być matkami, bo Naród wymiera, a mężczyzna, choć może wiele, dziecka jeszcze nie urodził - może też na razie? Warto więc porównać, co się $\mathrm{w}$ tej materii zmieniło od XVII wieku.

W przekonaniu wielu feministek kobieta w dawnych wiekach była tylko pokorną niewolnicą albo służebnicą mężczyzny, a wolność kobiet zaczęła się dopiero $\mathrm{w}$ XX wieku. Jest to zupełnie bezpodstawne mniemanie.

Przyjrzyjmy się, jak wyglądało życie kobiet w XVII wieku, kobiet z warstwy najwyższej, czyli pochodzących z magnaterii. Spośród wielu dziedzin historii do najtrudniejszych należy zawsze historia obyczajowości czy życia codziennego. O nim dowiadujemy się najczęściej przy okazji, bo nikt nie pisze o sprawach codziennych, które wszyscy znają, ale po latach te codzienne sprawy zmieniają się i wszyscy się dziwią, że życie codzienne wyglądało kiedyś zupełnie inaczej.

Słowa „magnat”, „magnateria” w Polsce XVII wieku informowały, że posiadacz tego tytułu miał na tyle duży majątek, aby zapewnić sobie odpowiednią pozycję społeczną. Nawet szlachcic wywodzący się ze starych zasłużonych rodów po utracie majątku nie był zaliczany do warstwy magnackiej. Jaki majątek powinien więc posiadać szlachcic, aby było można nazwać go magnatem? Nie jest to sprawa jednoznaczna. Zwykle w tym czasie majątki liczono liczbą posiadanych wsi. Według historyków za magnata uważano w Wielkopolsce posiadacza przynajmniej $20 \mathrm{wsi}^{1}$.

Majątki magnatów były ogromne, ale jednocześnie ich wydatki przekraczały niejednokrotnie ich dochody. Magnaci tracili fortuny na budowę wspaniałych rezydencji, fundowanie klasztorów czy kościołów, które miały uświetnić ich nazwiska lub stanowiły zadośćuczynienie Bogu za hulaszcze życie. Najwięcej kosztowały wyjazdy na sejmy, elekcje czy sprawowanie poselstw zagranicznych, a także udział w wojnach. Na przykład Albrechta Radziwiłła udział w elekcji w 1632 roku kosztował 32 tys. $\mathrm{zł}^{2}$. Jedno z najwspanialszych polskich poselstw obediencyjnych do papieża, sprawowane przez Jerzego Ossolińskiego, kosztowało go 200 tys. zł, przy rocznych dochodach sięgających zaledwie około 30 tys. $\mathrm{zł}^{3}$.

${ }^{1}$ W. Dworzaczek, Struktura społeczna szlachty, w: Dzieje Wielkopolski, t. 1, Poznań 1969 , s. 488.

2 A. S. Radziwiłł, Memoriale rerum gestarum in Polonia, oprac. A. Przyboś i R. Żelewski, t. 1, Wrocław 1968, s. 138.

${ }^{3}$ K. Opaliński, Listy [...] do brata Łukasza 1641-1653, red. R. Polak, Wrocław 1957, s. 259. W Polsce istniały monety o drobnych nominałach, co zmuszało do zabierania 
Wszystko to sprawiało, że większość magnatów tonęła w długach. Dlatego nie dziwi pazerność wielu z nich, gdy starali się zdobyć jakieś dobra, często $\mathrm{w}$ sposób nieuczciwy. $\mathrm{W}$ tych sporach miały też udział kobiety, zwłaszcza wdowy i córki walczące o spadki. Tak było w sporze żony hetmana Jana Chodkiewicza z córką Anną, która chciała obalić testament ojca. Ze zgorszeniem pisano wówczas: „Jeszcze rodzicowi nogi nie ostygły, już Waszmość za majętność chwytasz. Depcze Wasza Miłość Pani wolę ojcowską"4.

Mówiąc o kobietach magnatów, mamy na uwadze przede wszystkim ich żony i córki. Gwoli ścisłości historycznej należy wspomnieć także o innych kobietach, które przewijały się w życiu magnatów, a mianowicie wszelkiego rodzaju kurtyzanach wywierających czasami też znaczny wpływ na życie, nawet polityczne.

\section{WYKSZTAŁCENIE}

Magnaci dbali na ogół o wykształcenie swoich dzieci, nie tylko synów, ale także córek, bo - jak pisze Jan Karol Chodkiewicz - „głupim być szlachcicem nic sprośniejszego" ${ }^{\prime \prime}$. Dlatego wykształcenie dzieci przysparzało rodzicom niemało trosk. Starano się im dać gruntowne wykształcenie, zapewniając dobrych nauczycieli, a także wyjazdy za granicę na studia i w celu zdobycia ogłady. Dla matek ważniejsze było wychowanie domowe dzieci, które miało przygotować je do późniejszego samodzielnego życia. Jak widać z zachowanych korespondencji, dzieci często zachowywały tę troskę rodzicielską we wdzięcznej pamięci. Tomasz Zamojski, pisząc do matki z zagranicy, wyznawał: „Milsze mi jeno słowo własnej głowy twojej niż cudze mądrości i libra”. Tenże poświadczał, że "mądry syn starał się matkę cieszyć służąc Panu Bogu, ucząc się pilnie nauk i obyczajów przystojnych"6. Naturalnie w wychowywaniu młodych magnatów nieraz dochodziło do wypaczeń, gdy matka była

wozu na pieniądze. $1 \mathrm{złp}=30$ groszy $=5$ szóstaków $=10$ trojaków $=60$ pół groszy = 90 szelągów $=540$ denarów. Jeden grosz dzielił się na dwa półgrosze lub 3 szelągi. Najmniejszą monetą był denar, 18 denarów $=1$ grosz. Istniał talar srebrny $=3$ zł oraz czerwony złoty $=5 \mathrm{zł}$ polskich.

${ }^{4}$ J. Pietrzak, Wojna o majątek $i$ ciato hetmana, „Kierunki” 1973, nr 38, s. 2.

${ }^{5}$ W. Łoziński, Życie polskie w dawnych wiekach (wiek XVI-XVIII), Lwów 1907, s. 23.

${ }^{6}$ Tamże, s. 39. 
np. zbyt opiekuńcza i syna wychowywała w zniewieściałości, przesadnie dbając o jego zdrowie, jedzenie czy nawet upominając nauczyciela, aby nie był wobec syna zbyt wymagający. Znajdowało to potępienie w ówczesnych powiedzeniach satyrycznych, np. „Rośnie Jaś jak cielątko, wyrośnie z niego wołek?

Synowie magnatów uczyli się zasadniczo w kraju, ale także odbywali podróże zagraniczne. Natomiast do wykształcenia córek nie przykładano tak wielkiego znaczenia. Wysyłano je do szkół klasztornych, gdzie otrzymywały pewien zasób wiedzy, na którą składały się: umiejętność czytania i pisania, liczenia, czyli rachunków, oraz prac ręcznych - haftu czy prac domowych ${ }^{8}$. Wiedza ta zależała od poziomu szkoły i pojętności panny. Uczono je także katechizmu oraz prowadzenia życia religijnego, codziennej modlitwy, rachunku sumienia, chodzenia do kościoła, przystępowania do sakramentów.

Kobiety w tym czasie nie odgrywały, poza nielicznymi wyjątkami, dużego znaczenia w życiu politycznym. Dlatego ich wykształcenie nie musiało być wszechstronne. Wszakże w omawianym okresie wszystkie córki magnackie posiadały umiejętność pisania i czytania. Niektóre potrafiły nawet posługiwać się wyszukaną formą literacką i tworzyły sensowne opisy, listy oraz poezje. Dość powszechnie uważano, że córka powinna się wychować u boku matki, ucząc się prac domowych i zachowania w "towarzystwie". Wiedzę gospodarczą w sposób praktyczny młode niewiasty zdobywały $\mathrm{u}$ boku swych matek i guwernantek. Wiele $\mathrm{z}$ nich osiągnęło $\mathrm{w}$ tej dziedzinie niemałą biegłość, co pozwalało im, w razie wdowieństwa, nieźle gospodarować swoimi włościami. Zapewne niedościgłym wzorem była dla nich królowa Bona, która w swoich majątkach, stanowiących jej posag jako królowej, potrafiła znakomicie gospodarzyć. W swoim życiu zgromadziła ogromny majątek, znany $\mathrm{w}$ historii jako sumy bajońskie, które łatwowiernie pożyczyła i na zawsze straciła.

Panny po powrocie z klasztoru do domu rodzicielskiego przygotowywały się przy boku matki do życia i przyszłych obowiązków, które w zasadzie były dwojakie: albo wychodziły za mąż, albo szły do klasztoru. Dobór kandydata na męża sprawiał rodzicom wiele kłopotów, bo liczba kandydatów zależała od wielkości posagu. Posażna panna mogła kaprysić, a biedna raczej szukała okazji, aby się wydać. Jeśli zaś wstę-

${ }^{7}$ K. Opaliński, Satyry, oprac. L. Eustachiewicz, Wrocław 1953, s. 9.

${ }^{8}$ M. Gębarowicz, Materiaty źródtowe do dziejów kultury i sztuki XVII-XVIII w., Wrocław 1973, s. 114, 124 
powała do klasztoru, to rodzice musieli także liczyć się ze znacznymi wydatkami, bo magnat, pozwalając córce na wstąpienie do klasztoru, chciał, aby zajmowała tam ważniejsze stanowisko, najlepiej przeoryszy. Czynił też znaczne zapisy na konwent albo nawet fundował dla córki odrębny klasztor.

\section{MAŁŻEŃSTWA}

Rodzina była w tym czasie najsilniejszym fundamentem obywatelskim oraz narodowym i nawet $\mathrm{w}$ najgorszych czasach być nim nie przestawała. Pisze o tym wielki znawca dziejów życia społecznego w Polsce, Władysław Łoziński, w dziele Życie polskie w dawnych wiekach ${ }^{9}$. Jednakże okoliczności zawarcia małżeństwa i decyzje kobiety w tej materii bywały różne. Wydaje się, że nie miłość, ale względy materialne decydowały o wyborze partnera życiowego, choć i wielkie miłości się zdarzały. Trudno się dziwić, że tak było w XVII wieku, kiedy jeszcze w okresie międzywojennym $\mathrm{w}$ rodzinach chłopskich $\mathrm{w}$ Polsce takie postępowanie było chlebem powszednim. Najpiękniejsza panna nie wyszła za mąż, jeśli nie posiadała odpowiedniego posagu, czyli iluś mórg ziemi. Podobnie było i w rodzinach szlacheckich, gdzie każde małżeństwo było okazją do podbudowania fortuny lub wejścia $\mathrm{w}$ koligacje $\mathrm{z}$ możnymi rodami. Nic dziwnego, że zgryźliwy kronikarz, opisując małżeństwo dwórki Marii Ludwiki, Amaty Largeron, z Janem Kazimierzem Krasińskim, stwierdził: „Łaska królowej zmniejszyła ilość lat tak, że nowożeńcowi wydawała się młoda, aczkolwiek my nawet bez szkieł dostrzegaliśmy zmarszczki". A pasierb Zbigniewa Ossolińskiego powiedział o jego trzeciej żonie, że była to panna „w lata jak i w majętność bogata”"10. Tak więc o zawarciu małżeństwa bardzo często decydowała nie miłość, ale ekonomia.

Są jednak i przykłady miłości, jak na przykład u hetmana Jana Chodkiewicza czy Stanisława Żółkiewskiego. Najpiękniejszym i niedoścignionym przykładem gorącej miłości był Jan III Sobieski, który ze zdziwieniem konstatuje, że dawniej wierność jednej kobiecie nawet przez tydzień wydawała mu się niemożliwa do spełnienia ${ }^{11}$. Nie wiemy

${ }^{9}$ W. Łoziński, Życie polskie w dawnych wiekach..., s. 133-134.

${ }^{10}$ J. Ossoliński, Pamiętniki (1595-1621), Wrocław 1952, s. 12.

${ }^{11}$ Jan III Sobieski, Listy do Marysieńki, oprac. L. Kukulski, Warszawa 1962, s. 172, 128, 230. 
jednak, czy ta miłość rozkwitła po ślubie, czy istniała już przed nim. Nic nie wskazuje na to, aby tak koligacone małżeństwa były nieszczęśliwe. Każda panna raczej z ciekawością czekała, kogo los ześle jej jako męża, bo naturalnie o doborze kandydata najczęściej decydowali rodzice. $W$ rodzinach magnackich jednak panna miała okazję wyrazić swoje zdanie, bo przecież spotykamy się i z odmową. Na przykład Grizelda Zamojska, czternastoletnia wówczas panna, odmówiła swojej ręki A. Radziwiłłowi, choć trudno orzec, czy rodzice nie udzielili jej takiej rady. Bywały i małżeństwa zawierane przez porwanie panny wbrew woli rodziców. Pan młody zajeżdżał w nocy z pomocnikami i porywał pannę, najczęściej za jej zgodą, czasem nawet $\mathrm{z}$ pomocą matki. Panna wsiadała do karety, nie zapomniawszy uprzednio zabrać klejnotów i ubrań. W pobliżu czekał gdzieś ksiądz, który dobrowolnie lub pod przymusem błogosławił to małżeństwo. Porywano także panny ze szkół klasztornych. W zasadzie przy tych okazjach lało się morze atramentu $\mathrm{w}$ rozmaitych protestach i skargach, a rzadko krew ${ }^{12}$.

Małżeństwa zawierane $\mathrm{z}$ rozsądku często sprawiały, że wierność poślubionych była zagrożona, zwłaszcza w czasie wojen czy podróży dyplomatycznych. Moralność życia w tych czasach nie różniła się zbytnio od tej dzisiejszej, bo w rzeczy samej w tej dziedzinie pomysłowość ma swoje ograniczenia. Różnica między dawną moralnością a dzisiejszą jest taka, że wówczas wstydzono się swoich słabości, a dziś czyni się z nich powód do dumy, przechwałek i reklamowanie zła jako normalnej drogi ludzkiego postępowania.

Miejscem deprawacji młodych magnatów były zawłaszcza podróże zagraniczne, ale i w kraju nie brakowało przypadków zapewniania sobie rozmaitych utrzymanek, które potem wydawano za dworzan, najczęściej hojnie je uposażając. Przypadki te były powodem zazdrości i tłumaczenia się przed żonami. Innym powodem było pijaństwo i swawolny tryb życia małżonków. Bywały także - co prawda nieliczne - przypadki, że małżonkowie przed ślubem zastrzegali sobie wzajemną swobodę obyczajów ${ }^{13}$.

Panie nie były także bez winy i wśród nich zdarzały się przypadki niewierności. Nic dziwnego, że budowniczowie dworów radzili, aby pokoje pani domu znajdowały się obok pokoi pana: „Więc kto się

12 J. S. Bystroń, Dzieje obyczajów w dawnej Polsce. Wiek XVI-XVIII, t. 2, Warszawa 1976, s. 138.

${ }^{13}$ W. Czapliński, J. Długosz, Życie codzienne magnaterii polskiej w XVII w., Warszawa 1976 , s. 37. 
rogów boi, a żonkę ma po temu, na Boga obok z nią i przez próg tylko niech mieszka"14. Zdrady żon, opuszczanych przez mężów miesiąca$\mathrm{mi} \mathrm{z}$ powodu wojen lub podróży zagranicznych, znane są z różnych zapisów. Żona Janusza Radziwiłła, Zofia, zdradzała swego męża ze służącym Tatarzynem, za co mąż kazał go ściąć. Elżbieta Jordanówna, żona Mikołaja Ligenzy, gdy syn chciał ją rugować z majątku, zagroziła, że powie publicznie, z kim go spłodziła, a w ówczesnym prawie dzieci pozamałżeńskie, "bękarty”, nie miały prawa dziedziczenia. Znajdowało to także odbicie w licznych anegdotach. Na przykład takiej: Pani zdradzała męża z młodzieńcem, którego za to skazano na śmierć przez utopienie. Ten prosił ją o wstawiennictwo. Miała mu odpowiedzieć: „Już idź, bo moja łaska nie poradzi, po smacznym kąsku wody napić się nie wadzi"15.

Były to jednak, jak się wydaje, przypadki skrajne i odosobnione. Wiele żon magnackich to dobre matki, zapobiegliwe gospodynie, które pod nieobecność mężów potrafiły dobrze gospodarować majątkami i uczyć tego innych. Każda żona magnata miała liczny zastęp dwórek, zwany fraucymerem. Orszak magnatki tworzyły młode szlachcianki, oddawane na dwór, aby nauczyć się ogłady, gospodarności, rządzenia domem, a często także po to, aby znaleźć odpowiedniego kandydata na męża.

\section{3. ŻYCIE RELIGIJNE}

O pobożności niewiast magnackich niewiele jest wzmianek w źródłach, choć zapewne nie brakowało wśród nich osób religijnych. Wzmianki odnoszące się do tej dziedziny dotyczą przede wszystkim ich mężów. Należy jednak założyć, że - wbrew potocznym twierdzeniom - była to w większości grupa ludzi wierzących, choć trafiali się także niewierzący albo wierzący, którzy swoim życiem zaprzeczali religijnym zasadom moralnym, do których publicznie się przyznawali. Wiek XVII to czas nasilonej działalności Kościoła potrydenckiego, zwłaszcza od panowania Zygmunta III Wazy, który oddziaływał na innych własnym życiem gorliwego katolika. Wpływ Kościoła na życie wiernych był znaczny. Nic dziwnego, że religia odgrywała w życiu magnatów i ich rodzin

${ }^{14}$ Krótka nauka budownicza dworów, pałaców, zamków podtug nieba y zwyczaju polskiego, wyd. A. Miłobędzki, Wrocław 1957, s. 10.

${ }^{15}$ D. Nieborowski, Poezje, oprac. J. Dür-Durski, Warszawa 1961, s. 43. 
dużą rolę. Wielu z nich prowadziło życie głęboko religijne, np. Albrecht Radziwiłł nie tylko sam często leżał krzyżem, ale zmuszał służących, aby robili to samo i odmawiali godzinki. Jego pobożność przejawiała się w szacunku do służby i chłopów oraz w licznych datkach jałmużny na rzecz biednych. O poddanych zwykł mówić: "dobrodzieje to nasi”, $\mathrm{z}$ ich laski, my panowie, mamy pieniądze ${ }^{16}$. Nie był on wyjątkiem. Wielu magnatom praktyki religijne zabierały mnóstwo czasu. Wśród nich było słuchanie codziennej mszy, odmawianie różnych modlitw i umartwienia. Na przykład Tomasz Zamojski, jeśli nie był na mszy codziennie, dawał 10 zł na biednych, podobne wieści mamy o Władysławie Zasławskim czy hetmanie Stanisławie Żółkiewskim, który na wojnę nie wyruszał bez kilku kapelanów. Do tego dochodziły różnego rodzaje fundacje klasztorne, kościołów, kaplic a także fundacje mszalne - wszystko po to, aby po ich śmierci modlono się za ich dusze.

W powstawaniu pobożnych fundacji miały również znaczny udział niewiasty, które biorąc przykład z królowych fundujących klasztory, same przyczyniały się do rozszerzania chwały Bożej. Niewiasty decydowały się także często na dobrowolne przyjmowanie różnego rodzaju umartwień, od noszenia włosiennicy do różnych innych, nieraz bardzo dziwnych cierpień, np. Elżbieta Sieniawska gasiła świece własnym ciałem. Pobożność ówczesna wyrażała się przysłowiem: „Konia nie bij, sługi nie znieważaj, żony nie drażnij, jeśli chcesz spokój mieć"17.

Rzecz jasna nie brakowało wśród magnaterii także ludzi, co do których wiary mieli zastrzeżenia nawet ludzie świeccy, jak na przykład Jan Ostroróg, który pisał: „Jest wśród naszych katolików pewien rodzaj ludzi, którzy nie przynoszą żadnego plonu godnego swego wyznania"18. Ci ludzie dopiero w obliczu śmierci przypominali sobie o Bogu, jak to wynika chociażby z napisu na grobie Stanisława Lubomierskiego, który kazał napisać o sobie bez ogródek: „Tu leży grzesznik, fundator tego miejsca". Takie stwierdzenia odnoszą się zarówno do mężczyzn, jak i do kobiet.

„Nie ma nic pewniejszego jak śmierć i nic bardziej niepewnego, jak kiedy ta chwila nastąpi". Od śmieci nikt się nie wykupi - ani bie-

${ }^{16}$ A. Sajkowski, Od Sierotki do Rybeńki. W kręgu radziwittorwskiego mecenatu, Poznań 1965, s. $72-73$.

17 A. Grabowski, Starożytności historyczne polskie, t. 1, Kraków 1840, s. 357.

${ }^{18}$ J. Tazbir, Rzeczpospolita i świat. Studia z dziejów kultury w XVII w., Wrocław 1971, s. 133-134. 
dak, ani magnat. Dlatego także kobiety magnatów pamiętały, że śmierć nastąpi i myśl o śmierci towarzyszyła im zawsze. Znajdowało to wyraz w ówczesnych zapisach testamentowych czy budowie grobowców. Troska o zbawienie przejawiała się także $\mathrm{w}$ tym, aby przez akty miłosierdzia i jałmużnę zyskać jak najwięcej łask. Aleksandra Koniecpolska w testamencie wymieniła szereg swoich sług, którym należy zapłacić należne im pieniądze. Pieniądze płacono też uczestniczącym w pogrzebie biedakom, aby modlili się za duszę zmarłej. Oczywiście także duchowieństwu. Czasami magnatka pisała $\mathrm{w}$ testamencie o skromnym pogrzebie, o miejscu i rodzaju pochówku' ${ }^{19}$.

Pogrzeby odbywały się jednak zazwyczaj z wielkim przepychem. Przeciętnie zmarła czekała na pogrzeb od miesiąca nawet do kilku miesięcy. Trzeba było zawiadomić rodowych przez posłańców, przygotować wystrój kościoła, czyli zbudować castrum doloris, uszyć stroje żałobne dla służby, wymalować portret zmarłej, ściany kościoła wybić tkaninami itp. Czasami dopiero wtedy budowano kaplicę grobową, jeśli jej nie było, często też przewożono ciało do rodowych włości, oddalonych nawet kilkaset kilometrów. Zwłaszcza latem problem ten nastręczał wiele kłopotów. Oznacza to, że ciała były w jakiś sposób mumifikowane czy balsamowane. Na pewno usuwano wnętrzności i w specjalnym naczyniu przenoszono je do grobu ${ }^{20}$.

Sam obrzęd pochowania żony magnata był bardzo uroczysty, ale mniej wystawny niż jej męża. Żony i córki potrafiły też w czasie pogrzebu męża czy ojca doprowadzić do waśni i sporów, głównie o spadek.

\section{ZDROWIE I HIGIENA}

Wbrew przyjętym schematom magnaci dbali o swoje zdrowie i korzystali z usług dostępnych wówczas lekarzy. Często zmieniali powszechną wówczas bieliznę, o czym świadczą rachunki dla "praczek”. Wiele rezydencji było wyposażonych $\mathrm{w}$ sanitariaty i bieżącą wodę ${ }^{21}$. Ponadto rezydencje magnackie, położone zazwyczaj na wsiach, miały zdrowy klimat. $\mathrm{W}$ razie epidemii magnaci przenosili się $\mathrm{w}$ inne odległe

19 Tamże, s. 214-215.

20 Tamże, s. 217.

${ }^{21}$ E. Foltyniak, Wodociagi na świecie, w: Wodociagi w Polsce. Historia zabytki, architektura, red. A. Bochena, b.m. i r.w., s. 34 . 
miejsca, w ten sposób izolując siebie i najbliższych od grasujących epide$\mathrm{mii}^{22}$. W porównaniu z pałacem wersalskim, bez toalet, które zastępowały naczynia nocne, i stylem życia w czasach Ludwika XIV, higiena w Polsce była bez wątpienia na wyższym poziomie. Nasi myli się znacznie częściej. Ludwik XIV został pierwszy raz wykąpany dopiero $\mathrm{w}$ wieku siedmiu lat, co najlepiej świadczy o poziomie tamtejszej higieny.

\section{POŻYWIENIE}

Pożywienie kobiet magnatów było bardzo wykwintne, zwłaszcza na częstych ucztach. Jadano mięsa wołowe, wieprzowe, baraninę, drób, króliki i dziczyznę, która stanowiła ważne uzupełnienie menu. Za bardzo ważne danie uchodził bigos; uważano, że bez niego goście nie byliby ugoszczeni właściwie. Na przyjęciu podawano też ryby, nie tylko krajowe, ale także zagraniczne, a także ostrygi, ślimaki, żółwie, raki i kawior. Do tego dochodziły wszelkiego rodzaju przyprawy i owoce południowe, figi, rodzynki oraz desery z różnych rodzajów cukru. Potrawą, która w XVII wieku dotarła do nas i stała się powodem dumy wydającego przyjęcie, były pasztety. Na dworach utrzymywano specjalnych pasztetników, z których pierwsi byli w zasadzie Francuzami. Znano też kawę i to na lata przed wiktorią wiedeńską. Niestety, na uczty niewiasty rzadko bywały zapraszane, głównie z racji powszechnego na nich obżarstwa i pijaństwa. Gdy niewiasty były z jakiejś okazji obecne na uczcie, starano się wtedy o przystojniejsze zachowanie, zwłaszcza przy spożywaniu trunków, czyli można powiedzieć, że i wówczas kobiety łagodziły obyczaje.

\section{STROJE I ROZRYWKA}

Kobiety magnatów wyróżniały się strojem. Ustępowały w nim tylko żonom królewskim. Moda w tamtym czasie była także czymś naturalnym i zmieniała się bardzo często. Przybycie do Polski francuskich księżniczek z Ludwiką Marią rozpoczęło w Polsce okres mody francuskiej. Ką́liwa królowa pisała, że Polki ubierają się według mody panującej we Francji przed 15 laty. Ale polskie niewiasty chciały się

${ }^{22}$ W. Czapliński, J. Długosz, Życie codzienne magnaterii..., s. 42-46. 
przypodobać królowej i nadrabiały stracony czas tak szybko, że stawały się powodem zgorszenia moralistów i kaznodziejów, a nawet mężów. Krzysztof Opaliński pisał, że królowa tak mu żonę wystroiła, że tylko „cycków nie pokazuje, choć to alamodissimum"23. Przedtem dekolty w Polsce nie były znane, podobnie jak i zapewne liczne choroby, które nazywano powszechnie francuskimi. Kobiety magnatów nie miały w zasadzie wielu obowiązków, dlatego mogły poświęcać dużo czasu na toaletę i strojenie się. Cudzoziemcy przybywający do Polski dziwili się wielości biżuterii, którą nosiły, a także bardzo bogatym, drogim materiałom, z jakich były szyte ich stroje, takim jak złotogłowie, jedwabie czy inne materiały, których nazwy nie zawsze możemy dziś identyfikować. Jeśli chodzi o biżuterię, były to korony na głowy, pierścienie, bransolety czy naszyjniki.

Podobno wojewodzina ruska Wiśniowiecka miała koronę wartą 800 tys. złp. Podobnie zresztą ich mężowie lubowali się w klejnotach. Dlatego skarbce magnatów obfitowały w wielki zasób klejnotów, które miały też charakter lokaty pieniędzy. Wielu zamiłowanie do klejnotów upatruje we wpływach Wschodu od Moskwy do Stambułu. Wiadomo, że wówczas powszechna była słabość do wszystkiego co wschodnie, a więc szat, klejnotów, koni, stroju itp..$^{24}$

Rozrywką kobiet były bez wątpienia bale, często maskowe. Tańce odbywały się także po ucztach, w których brały udział kobiety, co raczej wobec nagminnego opilstwa nie było częste. Tańczono szczególnie w karnawale, no i oczywiście na weselach. Do rozrywek należało też oglądanie wędrownych kuglarzy. Specjalną rolę w umilaniu życia miały kapele oraz wszelkiego rodzaju muzykanci i śpiewacy. Na dworach utrzymywano większe lub mniejsze kapele oraz grupę śpiewaków. Opierając się na Starym Testamencie, w którym zanotowano, że króla Saula leczono muzyką z melancholii, mniemano, że muzyka ma własności lecznicze.

Rozrywką wielu niewiast było także myślistwo. Wiele $\mathrm{z}$ nich chodziło na polowanie, nawet na niedźwiedzie ${ }^{25}$. Królowa Bona przez to upodobanie doprowadziła do upadku dynastii Jagiellońskiej. Będąc

${ }^{23}$ K. Opaliński, Listy..., s. 319.

${ }^{24}$ W. Czapliński, J. Długosz, Życie codzienne magnaterii..., s. 111.

${ }^{25}$ W. J. Wysocki, Żelazne białogłowy i lwice kresowe. Kobiety w walce o catość Rzeczpospolitej, w: Lux ex Silesia. Księga pamiątkowa dedykowana Księdzu profesorowi Józefowi Mandziukowi w 70. rocznice urodzin, Warszawa 2013, s. 747. 
w zaawansowanej ciąży, uległa na polowaniu wypadkowi i urodziła przed czasem drugiego swego syna, Olbrachta, który zmarł ${ }^{26}$.

Wojna, będąca przede wszystkim domeną mężczyzn, nie była obca także niewiastom, i to we wszystkich okresach naszych dziejów. Wiele kobiet potrafiło $\mathrm{z}$ bronią $\mathrm{w}$ ręku chronić swoich posiadłości, zarówno przed wrogiem zewnętrznym, jak i zajazdami sąsiadów. Potrafiły także na czele służby same zbrojnie dochodzić swoich praw. Zwłaszcza Kresy Wschodnie pełne były nieustraszonych kobiet dobrze władających bronią. Gdy w 1638 roku król Władysław IV przyjechał do Wiednia, dla zabawy urządzono tam dla kobiet strzelanie z łuku do tarczy. Trzy pierwsze miejsca wzięły polskie dwórki królowej (kasztelanowa sandomierska Kazanowska, wojewodzina łęczycka Leszczyńska i panna Lukrecja Goldenszternianka, późniejsza starościna warszawska) ${ }^{27}$. Na kartach historii widzimy dziesiątki mężnych kobiet, które z bronią w ręku lub jako sanitariuszki uczestniczyły $\mathrm{w}$ bitwach, inspirowały i zagrzewały do walki żołnierzy lub same brały w nich czynny udział.

$* * *$

Z tego, co powyżej przedstawiono, wynika, że kobiety magnatów nie różniły się zbytnio od obecnych kobiet wywodzących się z wyższych sfer, tzn. spośród ludzi bogatych. Co do pożywienia, życia codziennego, strojów jest to porównywalne. Może jedynie nie słychać o pijaństwie kobiet, a pisze się o skromnym ich udziale w dość powszechnych wówczas ucztach. Kobiety wywierały wówczas wpływ na politykę, walczyły jak żołnierze, polowały, były oddanymi wolontariuszkami i pielęgniarkami. Jedynie, jeśli chodzi o życie rodzinne, to ówczesne panie stały znacznie wyżej od dzisiejszych. Dom, wychowanie dzieci, ich wykształcenie, przygotowanie do życia - były domeną oddanych matek, które w epoce częstych wojen cały ten ciężar brały na swoje ramiona. Natomiast na pewno mniejszy był ich udział w polityce (nie było jeszcze słychać o równouprawnieniu kobiet $\mathrm{w}$ tym względzie).

26 S. Grzybowski, Dzieje Polski i Litwy (1506-1548), Kraków 2000, s. 40.

${ }^{27}$ W. J. Wysocki, Żelazne białogłowy..., s. 747. 
Streszczenie. Artykuł opisuje życie kobiet ówcześnie najwyższej warstwy społecznej. A więc ich życie codzienne, a także wykształcenie, małżeństwa, życie religijne, zdrowie i higienę, pożywienie, stroje i rozrywki.

W przekonaniu wielu feministek kobieta w dawnych wiekach była tylko pokorną niewolnicą albo służebnicą mężczyzny, a wolność kobiet zaczęła się dopiero w XX wieku. W wielu dziedzinach życia jest to myślenie bezpodstawne.

Słowa kluczowe: kobiety; magnateria; obyczaje magnatów.

Abstract. The article describes the lives of women of the highest social stratum at that time, it means their daily lives - as well as education, marriage, religious life, health and hygiene, food, clothing and entertainment. In the opinion of many feminists, woman in the old days was just a humble slave or handmaid a man, and women's freedom began only in the twentieth century. In many areas of life this thinking is unfounded.

Keywords: women; aristocracy; nobility customs. 
